\title{
A Comprehensive Review on the Potential of Microfabricated Microneedles for Effective Systemic Delivery of Drugs
}

Temitayo Adeyemi, School of Pharmacy, Keele University, Keele

\begin{abstract}
The conventional drug delivery methods widely used are intravenous injection and oral administration. Microneedles are a new technology used for drug delivery, administered percutaneously. Microneedles are often presented in a series of multiple simple microneedle arrays used on the skin to facilitate systemic or topical drug delivery. There are several advantages to transdermal drug delivery, including sustained release, improvement in patient's compliance and elimination of first-pass metabolism.
\end{abstract}

This study is conducted as a review paper, with relevant information collated from multiple articles, journals and peer-reviewed papers. It reviews the physiology of human skin in detail, the structures and features of microneedles, and arrives at a comprehensive conclusion on their potential to effectively deliver drugs via the percutaneous route.

Results show that microneedles are used in therapeutic applications and are manufactured using various materials and fabrication techniques. They show great potential and are an emerging field in transdermal drug delivery; however, the physiology of the skin poses several challenges to research in the field. Drug delivery is limited by the stratum corneum and, hence, effective pharmacokinetics is affected.

This paper highlights some of the main frontiers in the use of microneedles as an important modern technique in percutaneous drug delivery. The advances in microfabrication technology and scalability in the configuration of microneedles is a technology that is expected to experience growth in the coming decades.

Keywords: Microneedles, microfabrication, stratum corneum, transdermal drug delivery, percutaneous route of administration 


\section{Background}

Oral delivery of medication is the oldest route of drug administration, but many drugs do not work as a result of poor oral bioavailability due to the first-pass metabolism that oral medication undergoes in the liver (Yeu et al., 2012; Ita, 2015). Transdermal drug delivery has proven to be a promising route of drug administration; however, the stratum corneum makes it difficult for most drugs to get into the systemic circulation. This is because the stratum corneum is a dead layer of cells. Furthermore, the skin has anatomical peculiarities and permeability varies in different parts of the body.

Hypodermic injections (Figure 1) were invented to counter these challenges in order to deliver medications directly into the bloodstream (Ogundele and Okafor, 2017). In clinical practice, hypodermic needles are used for drug delivery as they by-pass the stratum corneum (the skin barrier) and go directly into the bloodstream. While hypodermic needles are a reliable way of effective drug delivery into the body, they stimulate nerve endings, and are therefore painful (Ita, 2015). Using hypodermic needles may also result in discomfort, bleeding at the site of administration, risk of contamination and the need for a trained professional. According to Gill and Prausnitz (2008), drug delivery technologies strive to strike a balance between effective drug delivery and patient compliance. However, no route of drug administration is perfect.

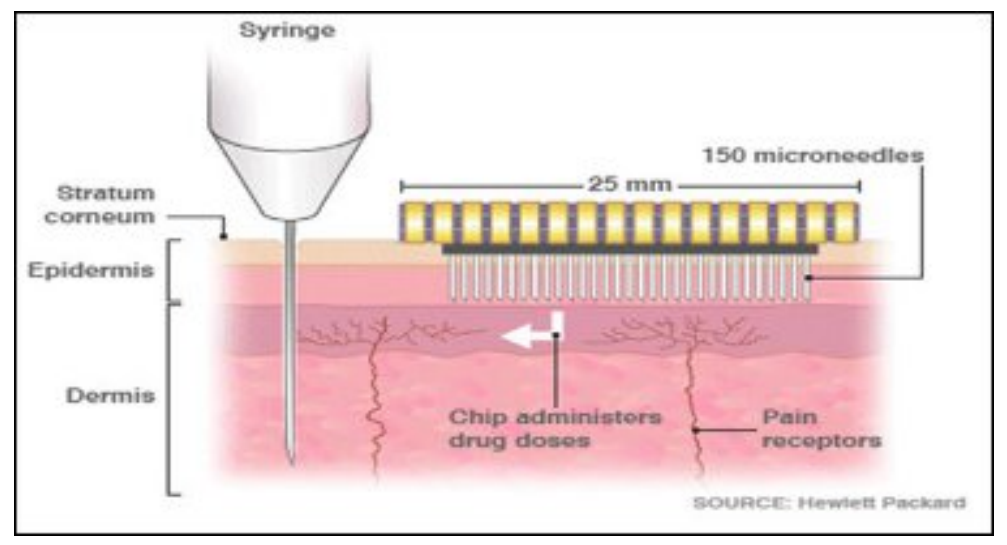

Figure 1: The nerve stimulation and needle length of a hypodermic medication compared to microneedles (MyLifesspan.com. 2018).

Although the concept of 'microneedles' (Figure 2) was first proposed about five decades ago, scientific research and technology advancements in the field did not begin until the mid-1990s. This was because little was known about microfabrication technology in the 1970s, and up-scale manufacture was only made possible after extensive scientific research. Vandervoort and Ludwig were the first people to make mention of this technology and regarded it as 'puncturing projections' (EscobarChávez et al., 2011). However, advances were not made until it was first patented in 
1971 by the inventors, Martin S. Gerstel and Virgil A. Place (Escobar-Chávez et al., 2011). Microneedles have since been used as a drug-delivering device around the world. Vandervoort and Ludwig also argued that microneedles could be a potential replacement for hypodermic needles (Figure 1) on the basis that microneedles deliver drugs to the epidermis and systemic circulation with little possibility of disruption of nerve endings (Figure 2) (Wu, 2008).

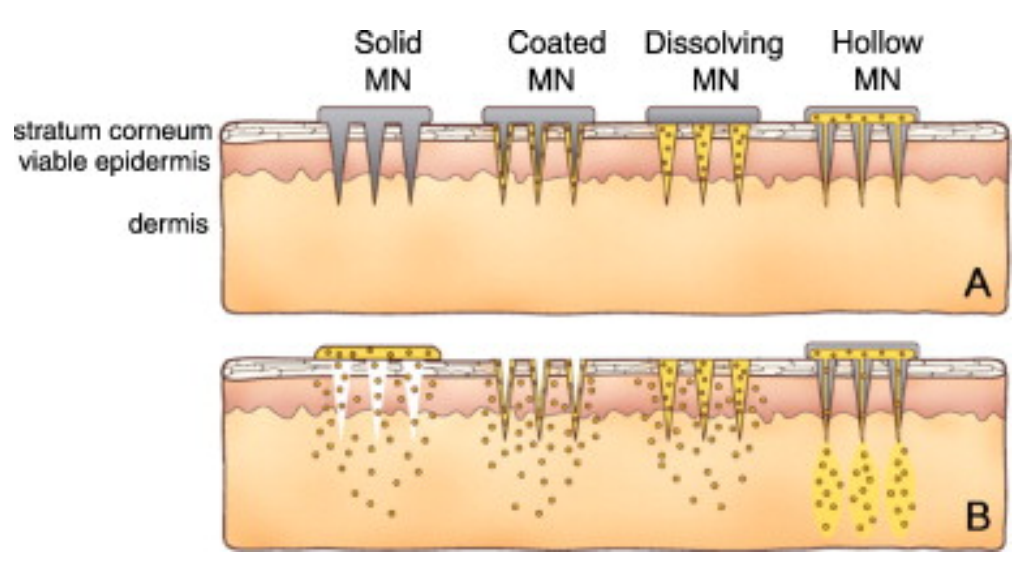

Figure 2: Different types of microneedles and their release mechanisms (Yeu et al., 2012).

In 1998, the first proof-of-concept of microneedles was brought to light in the scientific community when Henry et al. (1998) used silicon microneedles to deliver calcein across the human skin. It was discovered that silicon microneedles significantly increased the permeability of calcein. According to the authors, the magnitude of permeability was as much as four times the normal permeability of calcein. Since then, more than 350 research papers have been published on the use of microneedles (Yeu et al., 2012). More research is still being done with the aim of delivering medication through the skin into the systemic circulation and overcoming the barrier of the stratum corneum by using microneedles (Renxin et al., 2017, Skoog et al., 2015, Zhu et al., 2017, Manita et al., 2017, Yu et al., 2017). The understanding of microneedles and the research regarding their efficacy have been steadily advancing over the past decade. It is therefore worth understanding their potential in effectively delivering therapeutic medication into systemic circulation. This would further highlight how well they work in terms of pharmacodynamics.

\section{Introduction}

The stratum corneum is an effective barrier to prevent the entry of xenobiotics, infectious agents and other substances into the body (Wermeling et al., 2008). With the exception of drugs with high potency (where lower doses are needed for optimum 
target activation), the therapeutic delivery of drugs through the stratum corneum has been a major challenge. Over the years, transdermal drug delivery has proven to be of great therapeutic use. It has been associated with good patient compliance, which has led to the commercial success of products used for angina, chronic pain management, congestive heart failure, nicotine addiction and hormone replacement therapies, to name a few (Patil et al., 2012). Transdermal patches provide controlled and continuous drug release throughout the day, providing peaks and troughs of drug concentration in the bloodstream. However, transdermal patches have been linked with low permeability of drugs into systemic circulation, and they require significantly higher doses of drugs to attain loading or therapeutic doses.

The invention of microneedles has been thought to be a unique technological approach to enhance drug delivery across the stratum corneum by increasing permeability. Microneedle-based drug delivery usually involves the use of micrometrescale solid or hollow needles that pierce the stratum corneum without damaging nerve endings (Ogundele and Okafor, 2017). For example, a grid of holes is made in the skin by an array of stainless-steel microneedles, which then deliver medication through the micropores made on the surface of the skin.

When microneedles are manufactured, they are arranged in an array of needles that can be applied to the skin like a bandage. This is often regarded as a microneedle patch (Jacoby et al., 2015). Microneedles are generally fabricated in four main types: hollow, solid, coated and polymer microneedles (Figure 2). Hollow microneedles are similar to the regular hypodermic needles; however, they are a lot shorter in length. They are usually used to administer liquid formulation. Solid microneedles are used to create micropores in the skin, through which - after a patch is applied - the drug is delivered across the skin. Coated microneedles are coated with the drug, while polymer microneedles are 'made from polymers that can be dissolving, non-dissolving or hydrogel-forming' (Jepps et al., 2013; Ita, 2015). The specification(s) in which microneedles are fabricated is dependent on the type, geometry and material of the microneedle (Li et al., 2017). The table below details various techniques used for the fabrication of microneedles.

Type of microneedle
Fabrication methods

Polymer

microneedles 


\section{Dissolving microneedles}

Micro-moulding

\section{Metal}

microneedles

Laser cutting, wet etching, metal electroplating methods

\section{Silicon}

microneedle

\section{Ceramic}

microneedles

\section{Coated} microneedles

Hollow microneedles

Table 1: Fabrication techniques for different types of microneedles (Pérennès et al., 2006; Yoon et al., 2006; Migdadi et al., 2018: Adapted from Waghule et al., 2019).
Silicon dry-etching process, isotropic etching, anisotropic wet etching, dicing a silicon substrate and then acid etching, three-dimensional laser ablation

Ceramic micro-moulding and sintering lithography

Dipping or spraying the microneedles with an aqueous solution of increased viscosity to retain more formulation during drying and which contains a surfactant, the active agent and a stabilising agent

Microneedles can be dipped one time or more than one time into a coating solution, each individual microneedle can be dipped into a microwell containing drug solution or a film of drug solution previously formed on the roller can be applied

Layer-by-layer coating techniques

Micro-electromechanical systems (MEMS) techniqueslaser micromachining, deep reactive ion etching of silicon, an integrated lithographic moulding technique, deep X-ray photolithography, wet chemical etching and microfabrication 
Although there have been numerous animal studies involving the use of microneedles, only very few scientific studies have been conducted on humans. According to Kaushik et al. (2001), blindfolded, healthy volunteers could not tell the difference between the pain sensations of a microneedle array from a smooth surface. On the other hand, the volunteers could clearly distinguish the array from a 26-gauge hypodermic needle. Mikszta et al. (2002) tested the ability of microneedles to disrupt human skin, cause pain or induce inflammation. They compared ECG electrode pads with microneedle arrays and reported that when using microneedles of $200 \mu \mathrm{m}$ in length, there was trans-epithelial water loss, which indicated the successful breach of the stratum corneum. They also reported that, although pain perception in patients was negligible, many patients got skin irritation lasting up to 48 hours. Microneedles have since been available as solid microneedles for skin pre-treatment to increase skin permeability, as microneedles coated with a drug that dissolves in the skin, as polymer microneedles that encapsulate drug and fully dissolve in the skin, and as hollow microneedles for drug infusion into the skin (Figure 1) (Yeu et al., 2012).

The superficial layer of skin is pierced during the delivery of the drug using solid coated microneedles. However, the advancement of this technology has led to the fabrication of dissolvable/degradable and hollow microneedles that deliver drugs at a higher dose and are engineered to deliver a drug in the form of modified release (Prausnitz et al., 2006). Microneedles are now being used to deliver macromolecules such as immunobiologics, vaccines, oligonucleotides, growth hormones, proteins, insulin and peptides. This has been evolved to deliver drugs across the skin in a noninvasive manner.

\section{Delivery approach}

One common approach used for delivery of a drug through the skin is to poke the skin with the microneedles in order to create large pores. The microneedle can then be removed and the patch containing the drug over it applied. This creates a straightforward pathway for the drug to travel across the epidermal layer; and for a better effect, an electric field can also be applied (Waghule et al., 2019). Another approach is to cover the microneedle surface with a coating that contains the drug. These coated microneedles are then inserted into the skin where the drug dissolves from the coating (Sharma, 2017). A third approach is to dip the microneedles into a solution containing the drug and scrape the needles on the skin. This leaves the drug 
behind in the created abrasions (Waghule et al., 2019). Further approaches are the incorporation of the drug into a biodegradable polymer and creating the microneedles from the mixture (Waghule et al., 2019). Also, hollow microneedles can be designed in which the drug solution can be filled into the hollow space of the microneedles (Ripolin et al., 2017; Narayanan et al., 2018).

\section{Methodology}

This paper is divided into two parts: (1) the physiology of the skin and (2) the delivery of drugs across the skin for systemic uptake using microneedles. This is done to initially understand the organ (skin) extensively in order to later explore how drug delivery (through this organ - using microneedles) allows for physiological bioavailability of drug.

Searches for the works of literature relating to the subject topic were electronic and restricted to online journals, books and peer-reviewed articles. Searches involved the use of Google search engine, pub med, WebMD and Google scholar engines. Search phrases included: Skin physiology, stratum corneum, the anatomy of the skin, microneedles, properties of microneedles, types of microneedles, disadvantages of microneedles, advantages of microneedles, microneedles in practice, microneedles for drug delivery and the future of microneedles. The references include studies, clinical trials, systematic reviews and journal-published information on microneedles and the physiology of the skin.

\section{Part 1: Physiology of the human skin}

In order to understand that microneedles will potentially be efficacious enough to deliver a drug into systemic circulation through the skin, one must first understand the physiology of the skin and how it works.

The skin is the largest organ of the body, and it accounts for almost 15 per cent of the total body weight of an adult human. It is responsible for numerous crucial functions, which are essential for survival, and it protects the internal body from external chemical, physical and biologic xenobiotics. It also plays an important role in thermoregulation by preventing excessive water loss from the body. (Kolarsick et al., 2011). The mucous membrane that lines the surface of the body is also continuous with the skin. The skin consists of three different layers: the epidermis $(50-100 \mu \mathrm{m})$, dermis (1-2 mm) and hypodermis (1-2 mm), i.e. the subcutaneous tissue. The 
integumentary system (a network of the skin, hair, nails, glands and nerves) is formed by the skin and its derivative structures (Kolarsick et al., 2011; World Health Organization, 2009). The epidermis is the outermost layer of the skin, and it contains a group of cells that have been specifically differentiated. These cells are known as keratinocytes (Figure 3) and they have been differentiated to synthesise a protein known as keratin, which is a long, thread-like protein with a protective role (Kolarsick et al., 2011). A fibrillar structural protein, collagen, makes up the middle layer (dermis) of the skin. Collagen is the most abundant protein in any mammal, and it makes up more than 25 per cent of the proteins in the body. The dermis directly rests on the panniculus and is very thick (Figure 3). The panniculus contains lipocytes and it serves as a base for the dermis. Depending on the anatomical location, the thickness of the dermis can vary from one part of the body to another. The thickest part of the dermis is found on the back; where it is 30 to 40 times as thick as the overlying epidermis (William et al., 2016; Kolarsick et al., 2011). The skin also contains important features such as the pore of sweat gland duct and hair follicles. These are associated with sebaceous glands which help the skin and hair shaft to stay healthy (Figure 3). 


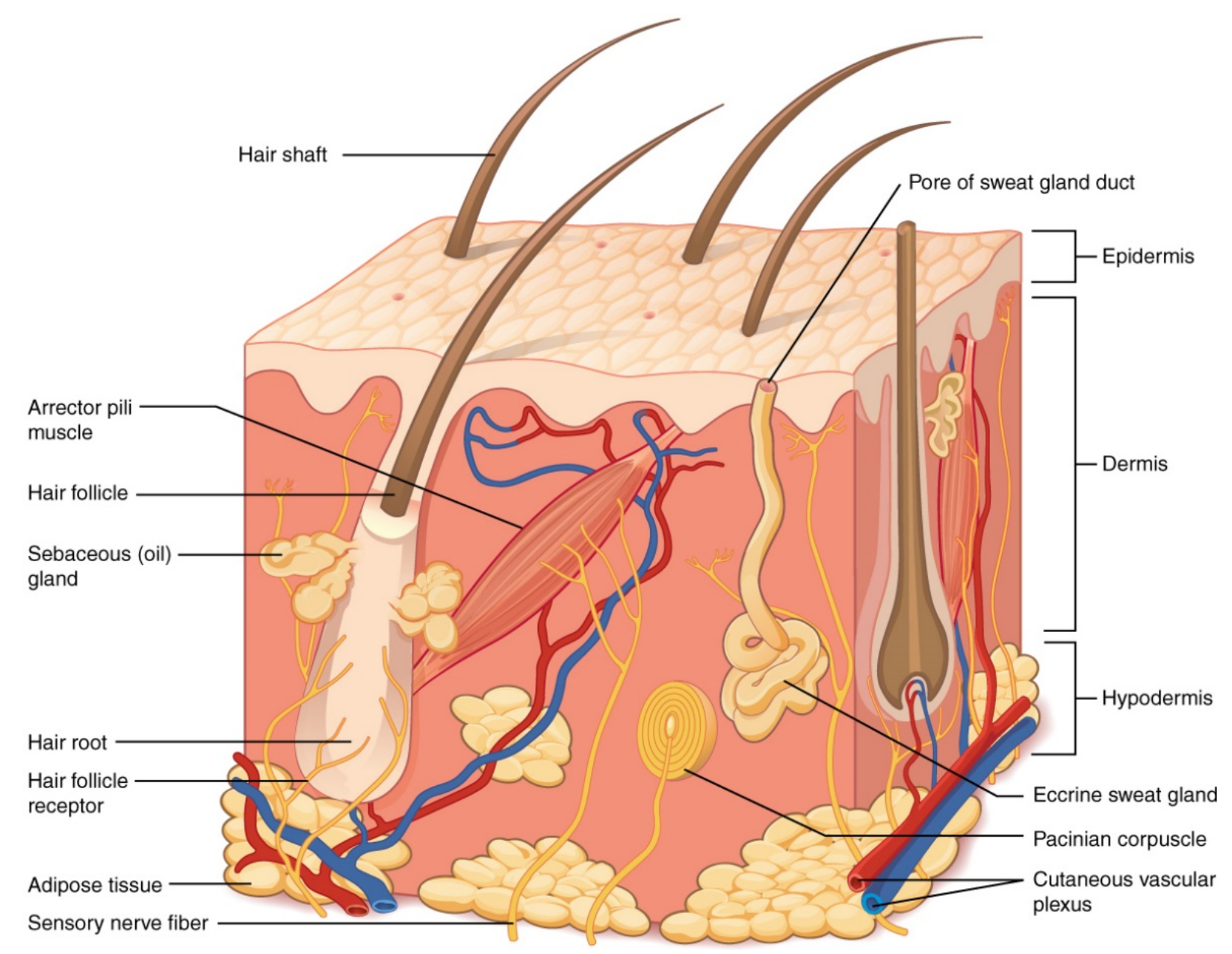

Figure 3: Structure of the human skin showing the three layers of the skin (BCcampus Open Education, 2018)

The epidermis also varies with anatomical location, with the thinnest layer measuring approximately $0.1 \mathrm{~mm}$ (found in the eyelids). It also comprises of the melanocytes (Figure 4.1), which are responsible for the skin's pigmentation. Furthermore, Langerhans' cells in the epidermis also play a vital role in antigen presentation and immune responses. Although the skin has numerous functional layers and cells - such as the papillary layer, the reticular layer and the hypodermis (responsible for lipid storage) - it is important to note that the layer most important to drug delivery is the epidermis (which contains the stratum corneum), hence the need to discuss the barrier more extensively. Nutrients that keep the epidermis functional are obtained from the highly vascularised network of cells in the dermis. According to the World Health Organization (WHO):

current knowledge of the function of the stratum corneum has come from studies of the epidermal responses to perturbation of the skin barrier such as (i) extraction of skin lipids with a polar solvent; (ii) physical stripping of the stratum corneum using adhesive tape; and (iii) chemically-induced irritation. 
All such experimental manipulations lead to a transient decrease of the skinbarrier efficacy as determined by trans-epidermal water loss. These alterations of the stratum corneum generate an increase of keratinocyte proliferation and differentiation in response to this 'aggression' in order to restore the skin barrier. This increase in the keratinocyte proliferation rate could directly influence the integrity of the skin barrier by perturbing: (i) the uptake of nutrients, such as essential fatty acids; (ii) the synthesis of proteins and lipids; or (iii) the processing of precursor molecules required for skin-barrier function - (World Health Organization, 2009).

\section{Stratum Corneum}

The most superficial layer of the epidermis is the stratum corneum (SC) and it is the main barrier to transdermal absorption of drugs. It is the layer exposed to the external environment with increased keratinisation (Kolarsick et al., 2011). The layers in the SC can be as thick as $30 \mu \mathrm{m}$ and as thin as $15 \mu \mathrm{m}$. The function of this layer of dry, dead cells is unique as it is responsible for thermoregulation by preventing the dehydration of the tissues underneath them. The layer also inhibits microbial penetration, hence acting as a protective barrier against microorganisms (Lever, 1949). The SC (Figure 4.1 ) is about $10-20 \mu \mathrm{m}$ thick and encloses a non-nucleated layer of flattened cells called corneocytes. It is fundamentally composed of bundles of the protein keratin, which are permanently bound to each other and cross-linked by lipids. The dry weight of SC is about 60 per cent keratin. During the differentiation of keratinocytes, lamellar bodies are actively pumped out of the cell giving rise to lipid formation in the cell. (William et al., 2016; Kolarsick et al., 2011). These lipids are then moved to the intercellular space (ICS) between corneocytes. The cohesion of the SC is further enhanced by the interconnecting membrane junctions. 

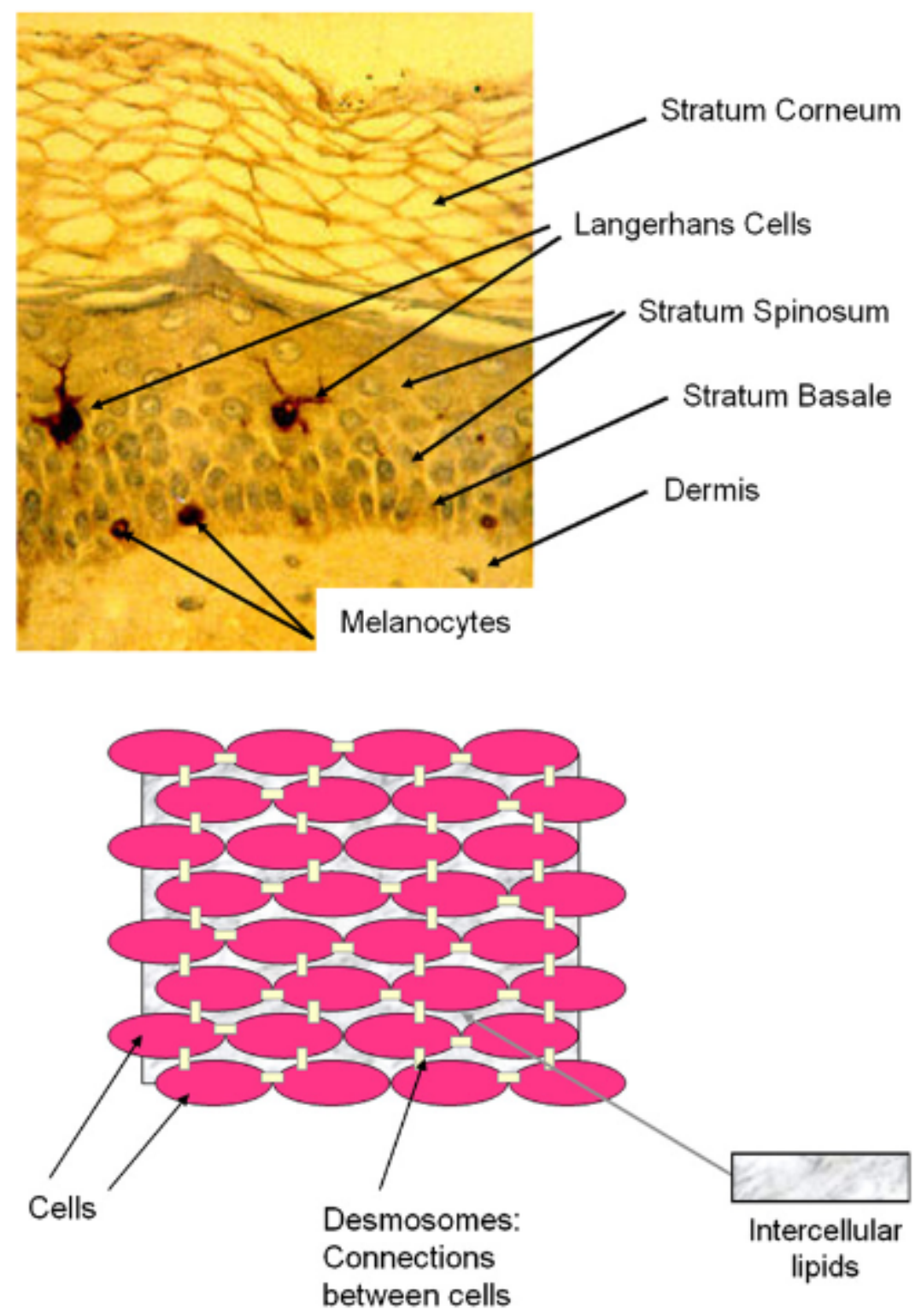

Figure 4.1: Micrograph of the upper dermis and epidermis showing the layers and major cell types (adapted from Wickett and Visscher., 2006)

Figure 4.2: A 'Bricks and Mortar' model for human stratum corneum illustrating the corneocyte 'Bricks', the intercellular lipid 'Mortar', and the desmosomes connecting the corneocytes (adapted from Wickett and Visscher, 2006)

The cells in the SC are completely shed periodically (every 3-4 weeks) when replacement cells from the granular layer or stratum granulosum (SG) are pushed up (Lever, 1949). The SG - although only a few cells thick - is a crucial component of the epidermis as this is the region of the skin where the pivotal transformation that forms the SC barrier occurs. Keratohyalin granules and lamellar bodies are transformed into the corneocytes or squares that form the SC by the digestion of nucleus and cytoplasm. The resulting corneocyte or squama is a hexagon or pentagon of flattened cells approximately $25 \mathrm{~mm}$, with a surface area of approximately $1000 \mathrm{~mm}^{2}$ and a thickness of approximately 0.5 to $1.0 \mathrm{~mm}$ (Wickett and Visscher, 2006). 


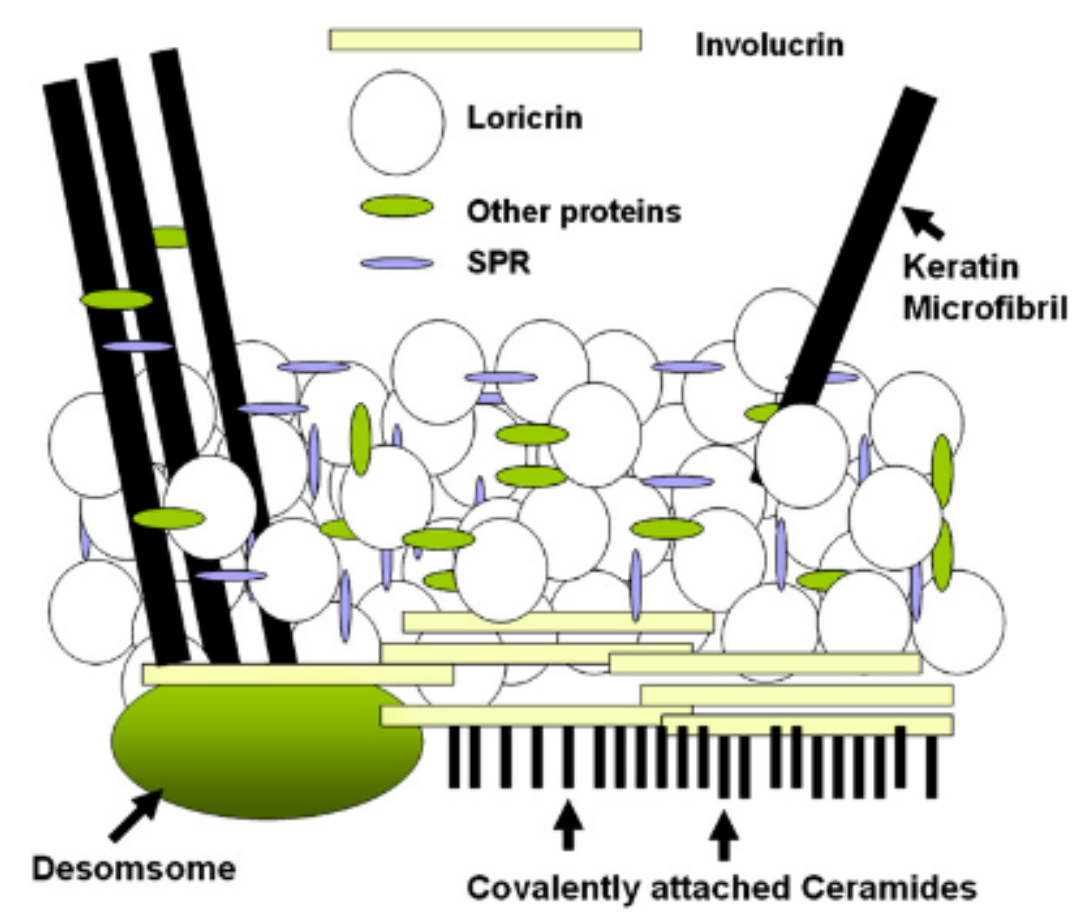

Figure 5: The corneocyte envelope as proposed by Steinert and Marekov (1995)

The SC is often regarded as a brick wall due to the presence of the corneocytes which have resistant cell envelopes and keratin microfibrils (Figure 5). These cell envelopes and keratin microfibrils are regarded as bricks and the layers of lipids contained between the cells are regarded as mortar (Wickett and Visscher, 2006). The lipid, or mortar, is the crucial layer that allows for waterproofing of the SC. As part of continuing literature, bricks have been shown to be linked by desmosomes (Figure 4.2). Formed from a family of proteins called intermediate filaments, keratins form part of the cytoskeleton of nucleated cells and they act as a crucial structural component of skin, hair and nails. As keratin is being made in a cell, an acidic type I keratin is made simultaneously as a form of neutral to basic type II keratin (Wickett and Visscher, 2006). Acidic proteins contain more negatively charged amino acid side chains while basic proteins contain more positively charged side chains. Thus, this allows the interaction of two a-helical proteins resulting in a structure known as coiled-coil. During the transformation of keratinocytes into corneocyte, coiled-coils aggregate and form microfibrils. The structural integrity of keratinocytes is maintained by coiled-coils; hence, a poor or unstable assembly of coiled-coils could result in fragile keratinocytes. This instability can cause ruptures and lead to blistering diseases (Wickett and Visscher, 2006).

Filaggrin (filament-aggregating protein) is a protein that contains high levels of positively charged amino acids. It is also involved in the aggregation of the keratin coiled-coils, which have an overall negative charge. After this structural activity has 
been completed, filaggrin is then digested by proteolytic enzymes. The result of this produces the amino acid components of the natural moisturising factor (NMF) of the SC. NMF contains lactate and pyrrolidone carboxylic acid (PCA), and these moisturisers are crucial in the maintenance of hydration of the SC, thus allowing flexibility and proper desquamation (Scott et al., 1982). At the lower layers of the epidermis, a normal phospholipid bilayer cell membrane is contained in the keratinocytes. However, phospholipid membranes are too permeable to water and won't survive exposure to air in a dry environment. Hence, at the SG, the cell membrane of the keratinocyte is transformed into the resistant cell envelope of the corneocyte. Based on the research by Peter Steinert, the schematic representation of the SC cell envelope is shown in Figure 5.

The lamellar bodies (mortar) found in the SG contain lipids, which are released into the ICS during the formation of the SC. These lipids include cholesterol, cholesterol esters, glucosylceramides and long-chain fatty acids (Figure 6). In the ICS, glucosylceramides are converted to ceramides. The lipids organise into multiple layers between the SC cells as shown in Figure 7. Mortar is crucial to the barrier function of skin, and ceramides (Figure 7) are pivotal to the organisation and functioning of the barrier. The surface of the SC has a pH of approximately 4 to 5.5 (acidic). The 'acid mantle' of the skin is known to aid in the protection of the skin surface against colonisation by bacteria. Bricks and mortar are very specialised and they work in accord to produce covering for the skin, which is remarkably flexible and protective. A healthy SC defends the body against dehydration, external toxins and bacterial assault as well as protecting the more fragile keratinocytes below from mechanical disruption. 


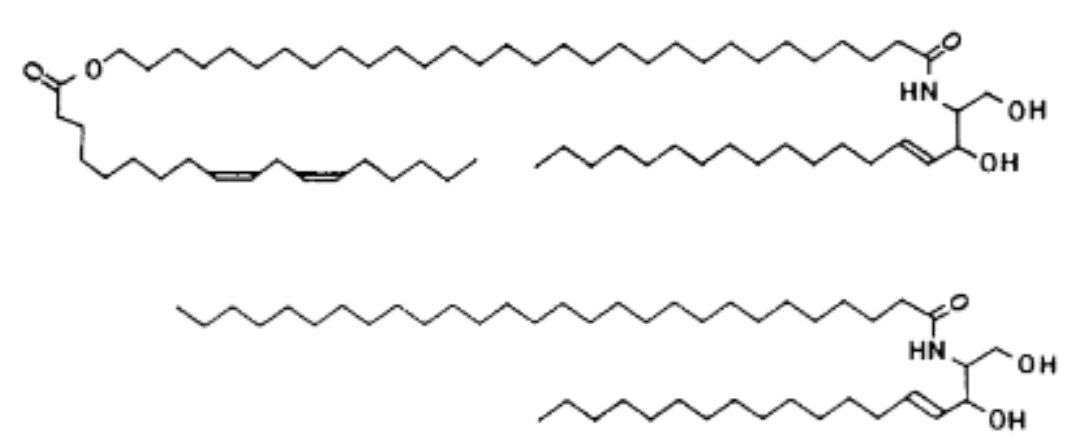

Figure 6: Schematic representation of the chemical structure of ceramides (Adapted from Wickett and Visscher, 2006)

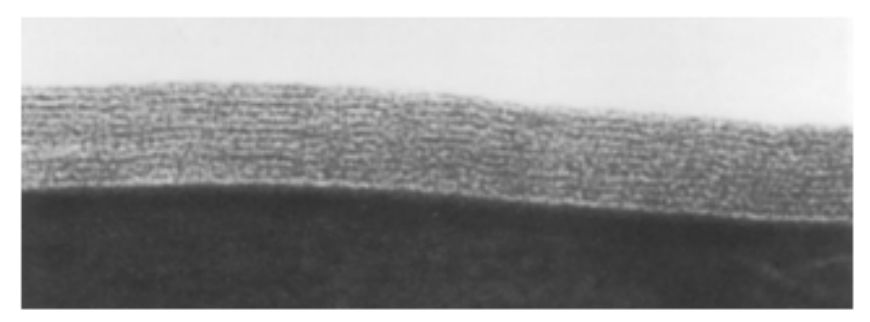

Figure 7: Normal lipid lamella at the third tape strip. (magnification, 3,200,000) (Adapted from Wickett and Visscher, 2006)

\section{Part 2: Delivery of drugs across the skin for systemic uptake using microneedles}

Microneedles have been studied in recent decades by researchers in attempts to enhance the delivery of drug through the transdermal route as well as in the overcoming of limitations presented in conventional approaches (Waghule et al., 2019). Compared to conventional approaches, microneedles are thought to be the hybrid of both hypodermic needles and the transdermal patch. As a comparison, Iontophoresis and electroporation are conventional electric methods which also improve the permeability of drug by creating nano-sized pores in the skin. However, this is only up to a certain extent and it fails for large molecules (Sharma, 2017). The major aim of the development of this technology was to create micron-size transport pathways which are large enough to permit drug transport but smaller than holes by hypodermic needles (Williams et al., 2004). However, microneedles have an improved therapeutic advantage and they give highly accurate and reproducible results (with minimum inter-subject variability in bioavailability) (Waghule et al., 2019). Although they have a vast number of advantages, they also possess some limitations (see Table 2) 
Microneedle arrays are thin tubes of solid or hollow needles that are used to breach the SC, thereby accessing microcirculation in the skin. This transdermal delivery of a drug is achieved by microneedles with an external radius of $150 \mu \mathrm{m}$, ranging between

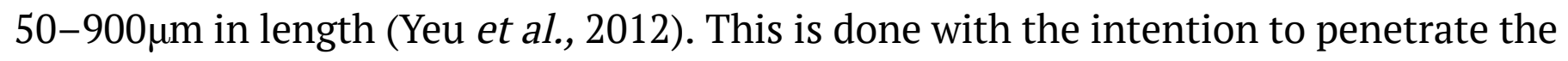
epidermis - which is $70-200 \mu \mathrm{m}$ deep - without penetrating the deeper dermis, thus delivering a pain-free administration of small and large molecular-weight pharmaceutical medications (Larrañeta et al., 2016). In the manufacture of microneedles, various materials have been adapted over the years, including silicon, metal, polymer, glass and ceramic (Ita, 2015; Ogundele and Okafor, 2017). Although microneedles are made to also penetrate the dermis, they are also short so that they cannot penetrate the dermal blood vessels.

Larrañeta et al. (2016) showed that microneedles did not leave skin infected after use. Their report also showed that patients can reproducibly insert microneedles into the skin without the need for any 'aid' device. Before the application of a drug-loaded patch, solid microneedles are used for the creation of micropores in the skin to enable the diffusion of drug content across the skin (Prausnitz et al., 2006). However, hollowbore microneedles could be administered using a pressure-driven flow of drug or diffusion through a lumen. In vivo studies have shown that microneedles have been able to deliver drugs such as vaccines, oligonucleotides, insulin and peptides (Larrañeta et al., 2016). There are advantages and disadvantages in the use of microneedles, these are detailed in the table below:

\section{Advantages}

Solid microneedles could be used along with transdermal patches in order to increase the rate of diffusion. The methods involved include the poking of holes in the skin to increase permeability and then using a drug-infused transdermal patch to facilitate diffusion into the blood stream, or coating needles with a drug

\section{Disadvantages}

Microneedles can be difficult to apply on the skin; and proper application techniques are required to be learnt by the administering clinician. Microneedles insertion requires precise technique at a specific force to avoid breaking or bending before insertion, thus impairing dosing (Gill and 
Microneedles can be fabricated from a range of materials, including metals, silicon, silicon dioxide, polymers, glass and other materials (Birchall, 2006) in a consistent and cost-effective manner.
If the concentration of drug increases under the dermis, there could be physically observable inflammation. More so, skin irritation could occur due to allergy or skin sensitivity (Indermun et al., 2014).
The absence of nerve stimulation that results in pain or bleeding make microneedles more clinically appropriate (particularly in paediatric vaccination and for needle-phobic patients). Hence, microneedles reduce the chances of pain, infection and injury (Donnelly et al., 2010, Hirobe et al., 2015, Indermun et al., 2014).

The delivery mechanism in microneedles is not based on diffusion, and thus, when drug is infused directly within the epidermis, it can more readily reach its site of action (Jasim et al., 2015).
Microneedles are incredibly small and very much thinner than the diameter of a hair, hence microneedle tips can be broken off and left under the skin. Microneedles specifically made of metal, stainless steel or silicon have high risks of fracture and leaving fragments in the skin (Hirobe et al., 2015).
Advances in the applications of microneedles in transdermal drug delivery is slow (SerranoCastañeda et al., 2018).
Microneedles avoid first-pass metabolism and, therefore, there is rapid penetration of drug directly into the blood stream (Alexander et al. 2.012.).
Microneedles require other micro-tools and microelectronics to be mass produced (Indermun et al., 2014). 
Microneedles can provide direct, controlled delivery of small molecules, macromolecules, vaccines or nucleic acids into the viable epidermis (Birchall, 2006, Indermun et al., 2014).
Microneedles can only be inserted into the skin if they have the correct shape and adequate physical properties (Donnelly et al., 2010).

Hollow needles could eventually be used with drug patches and timed pumps to deliver drugs at specific times. Furthermore, even smaller microneedles could provide highly targeted drug administration to individual cells (Escobar-Chávez et al., 2011).

Single-use needles are easily disposable and potentially biodegradable (Serrano-Castañeda et al., 2018).

Table 2: Table detailing information regarding the advantages and disadvantages of microneedles (adapted from Serrano-Castañeda et al., 2018; Ogundele and Okafor, 2017)

Although it was envisioned that low-cost microneedle arrays would be used for drug delivery, for many decades small needles that were used for research were individually hand-crafted. However, not until the 1990s was the microelectronics industry supplied with equipment that aided in microfabrication (Yeu et al., 2012). These tools were used extensively to produce microneedles that were suitable for application in the pharmaceutical community. The first fabricated array of microneedles was manufactured out of silicon. This has since been improved to include metal, polymer, glass and ceramic fabrications, with many arrays being fabricated in different sizes and 
shapes. The methods of microneedle fabrication have always been based on conventional techniques, which involve laser cutting, silicon etching, micromoulding, of adding, removing and copying microstructures utilising photolithographic processes, and metal electroplating (Larrañeta et al., 2016; Yeu et al., 2012).

There are currently more than 80 active clinical trials studying the application of transdermal administration of drugs to enable drug availability systemically. There have been gradual clinical research successes in the field of transdermal drug delivery with fewer than 20 transdermal patches on the market. While the transdermal market is based on fewer than 20 drugs, it is worth more than $\$ 31$ billion. This limited number of drugs is directly associated with the SC. This is because, before being absorbed into circulation and taken up by blood vessels in the upper papillary dermis, the drug must first cross the SC (Waghule et al., 2019).

Regarding the physiology of the skin, the numerous advantages that come with using microneedles has led to an increase in research in this area. As with normal transdermal skin patches, microneedles have minimal invasiveness. Although there are still studies continuing in this field, it has so far been reported that there has been no bleeding or microbial infection following the use of microneedles (Wermeling et al., 2008).

However, according to Ita et al. (2015) and Waghule et al. (2019), there is a chance of infection if the skin pores do not close properly after using microneedles or if the needles are not sterile. Pharmaceutical agents can be delivered locally as the drug can diffuse into the dermis layer of the skin. Hence, some medications can be administered locally to avoid systemic side effects by avoiding first-pass metabolism. It has also been useful to see a rise in patient compliance as microneedles do not stimulate nerve endings, and therefore are not painful (Escobar-Chávez et al., 2011). Furthermore, frequent dosage is not required as microneedle patches can be administered as a controlled-release medication. While these might appear appealing to patients, the use of microneedles to deliver medication systemically is flawed.

In the application of microneedles, Wermeling et al. (2008) evaluated a transdermal naltrexone patch in healthy human volunteers with and without pre-treatment of the skin with microneedles, and showed that, although microneedle patches and naltrexone patches were well tolerated, there were still systemic side effects. Furthermore, the claim made about patients' compliance to microneedles was shown 
to be flawed when a report found that needle-based phobia was experienced by some patients that were administered a dose array of microneedles, even though nerve endings were not stimulated (Wermeling et al., 2008).

After microneedles are used, they are often removed and disposed of inappropriately. Lanke et al. (2009) published a paper which investigated the invitro transdermal delivery of long-term medication holographic (LMH) across hairless rats treated with various enhancement strategies. The authors reported that the LMH interacted with the SC barrier, and even though drug delivery was increased, the SC was almost completely disrupted (Lanke et al., 2009). In the context of skin physiology, this could affect the epidermis and the SC barrier at the site of administration, leading to increased permeability and susceptibility to xenobiotics.

Furthermore, hair pores in the skin may become blocked when microneedles are broken off in them. This could open the body up to a series of infections and cause anatomical disruption of the cells underneath the SC. Since microneedles are much thinner than hairs in the skin, they could make it difficult for another administration of a microneedle patch on the same site of administration (Ita, 2015). For worldwide clinical application of microneedles, some challenges still must be addressed. These include poor control of controlled drug release, poor mechanical strength of microneedles and limitation of the loading dose of a drug using microneedles (Yeu et al., 2012; Ita, 2015).

Applications of Microneedles

Medical and Pharmaceutical Applications of Microneedles

Study

Outcome
Reference

(s) 


A transcutaneous
immunisation system
by microneedle array
for soluble and
particulate antigens.

Enhanced delivery of hydrophilic peptides in vitro by

transdermal

microneedle pre-

treatment. Improved

genetic immunisation

via micromechanical

disruption of skin.
Use of microneedles for

permeation of peptides with

different molecular weights.

Microneedles can remarkably

enhance the transdermal

delivery of all hydrophilic

peptides and be used for safe vaccination.

An array of solid microneedles of $150 \mu \mathrm{m}$ in length was used to make the skin more permeable (experiment done on pig's ear) and facilitate transport of peptides.
Matsuo et

al. (2002).
Mikszta et

al. (2002),

Zhang et al. (2014)
Influence of

microneedle shapes

on skin penetration

for continuous in vivo

glucose monitoring.

Microneedle-based

automated therapy for

diabetes mellitus.
Hollow microneedles made of silicon can determine the amount of blood glucose through a sample of interstitial fluid.
Khanna et

al. (2008),

Chua et al. (2013) 


\section{The effect of iontophoresis and microneedles for transdermal delivery of methotrexate.}

Transdermal delivery of microneedles to the skin in medication to humans.
Synergistic 25 -fold

enhancement of delivery in vivo in combination (microneedleiontophoresis), compared to each one alone.
Vemulapalli et al. (2008).

Wermeling et al. (2008).

naltrexone in a transdermal patch. This human proof-ofconcept study demonstrated the systemic administration of hydrophilic medication using a microneedle for enhanced transdermal delivery.

Clinical evaluation of Silicon microneedles using 0.45 Levin et al. a microneedle device for the intradermal delivery of an influenza vaccine. Safety and efficacy of a microneedle device for influenza vaccination in healthy adults. mm long (MicronJetTM) for injecting the influenza antigens very close to the skin's dendritic cells. MicronJetTM gives a superior response to influenza vaccination and warrants further clinical evaluation. The microneedle injection device is effective, safe and reliable.

(2014) Van Damme et al. (2009). 


\begin{tabular}{|c|c|c|}
\hline $\begin{array}{l}\text { Bacillus Calmette- } \\
\text { Guérin (BCG) } \\
\text { vaccination using a } \\
\text { microneedle patch. }\end{array}$ & $\begin{array}{l}\text { Vaccination patch coupled with } \\
\text { microneedles, preloaded with } \\
\text { BCG for the treatment and } \\
\text { prevention of tuberculosis. }\end{array}$ & $\begin{array}{l}\text { Hiraishi et } \\
\text { al. (2011). }\end{array}$ \\
\hline $\begin{array}{l}\text { Preliminary } \\
\text { technological } \\
\text { assessment of } \\
\text { microneedle-based } \\
\text { dry electrodes for } \\
\text { biopotential } \\
\text { monitoring in clinical } \\
\text { examinations. }\end{array}$ & $\begin{array}{l}\text { Microneedle-based dry } \\
\text { electrodes tested in ECG, EEG } \\
\text { and EMG are comparable to wet } \\
\text { electrodes in static conditions } \\
\text { and better in ECG dynamic } \\
\text { conditions. }\end{array}$ & $\begin{array}{l}\text { Forvi et al. } \\
\text { (2012). }\end{array}$ \\
\hline $\begin{array}{l}\text { Coated microneedles } \\
\text { for transcutaneous } \\
\text { delivery of live virus } \\
\text { vaccines. }\end{array}$ & $\begin{array}{l}\text { Silicon microneedles coated by a } \\
\text { method of spray, containing } \\
\text { adenovirus antigen and virus } \\
\text { Ankara that stimulated CD8 } \\
\text { cells of the immune system. }\end{array}$ & $\begin{array}{l}\text { Vrdoljak et } \\
\text { al. (2012). }\end{array}$ \\
\hline $\begin{array}{l}\text { Laser-engineered } \\
\text { dissolving } \\
\text { microneedles for } \\
\text { active transdermal } \\
\text { delivery of nadroparin } \\
\text { calcium. }\end{array}$ & $\begin{array}{l}\text { Development of laser- } \\
\text { engineered dissolving } \\
\text { microneedle arrays fabricated by } \\
15 \% \mathrm{w} / \mathrm{w} \text { poly (methyl vinyl } \\
\text { ether-comaleic anhydride) with } \\
\text { nadroparin calcium. The } \\
\text { microneedles offer immense } \\
\text { potential as a relatively low-cost } \\
\text { functional delivery system. }\end{array}$ & $\begin{array}{l}\text { Gomma et } \\
\text { al. (2012). }\end{array}$ \\
\hline
\end{tabular}




\begin{tabular}{|c|c|c|}
\hline $\begin{array}{l}\text { Droplet-born air } \\
\text { blowing made } \\
\text { dissolving } \\
\text { microneedle. }\end{array}$ & $\begin{array}{l}\text { Developed biodegradable } \\
\text { microneedles by the blowing } \\
\text { method that are loaded with } \\
\text { insulin. }\end{array}$ & $\begin{array}{l}\text { Dong et al. } \\
\text { (2013). }\end{array}$ \\
\hline $\begin{array}{l}\text { Targeted delivery of } \\
\text { anti-glaucoma drugs } \\
\text { to the supraciliary } \\
\text { space using } \\
\text { microneedles. }\end{array}$ & $\begin{array}{l}\text { Use of hollow microneedles } \\
\text { loaded with a drug for the } \\
\text { treatment of glaucoma applied } \\
\text { in the eye (space intraciliary) as } \\
\text { a new alternative for the } \\
\text { treatment. }\end{array}$ & $\begin{array}{l}\text { Kim et al. } \\
(2014) .\end{array}$ \\
\hline $\begin{array}{l}\text { Microneedle delivery } \\
\text { of verapamil } \\
\text { hydrochloride and } \\
\text { amlodipine besylate. }\end{array}$ & $\begin{array}{l}\text { Microneedles increased } \\
\text { penetration of verapamil } \\
\text { hydrochloride and amlodipine. } \\
\text { It is possible to generate } \\
\text { transdermal microneedle } \\
\text { patches for these drugs. }\end{array}$ & $\begin{array}{l}\text { Kaur et al. } \\
\text { (2014). }\end{array}$ \\
\hline $\begin{array}{l}\text { Development and a } \\
\text { characterisation of a } \\
\text { pravastatin } \\
\text { transdermal patch } \\
\text { coupled with solid } \\
\text { microneedles. }\end{array}$ & $\begin{array}{l}\text { Used a Dermaroller }{ }^{\circledR} \text { to increase } \\
\text { the permeation of sodium } \\
\text { pravastatin formulated in a } \\
\text { transdermal patch. The } \\
\text { pravastatin penetration used } \\
\text { microneedles ( } 250 \mu \mathrm{m} \text { and } 2250 \\
\mu \mathrm{m} \text { of lengths) and obtained } \\
\text { viable results to achieve a } \\
\text { therapeutic equivalent dose of a } \\
10 \mathrm{mg} \text { tablet. }\end{array}$ & $\begin{array}{l}\text { Serrano- } \\
\text { Castañeda } \\
(2014) .\end{array}$ \\
\hline
\end{tabular}




\begin{tabular}{|c|c|c|}
\hline $\begin{array}{l}\text { Drug-coated } \\
\text { microneedles for } \\
\text { treatment of oral } \\
\text { carcinomas. }\end{array}$ & $\begin{array}{l}\text { Development of coated } \\
\text { microneedles for direct and } \\
\text { minimally invasive intratumoral } \\
\text { delivery of anti-cancer drugs. }\end{array}$ & $\begin{array}{l}\text { Ma et al. } \\
\text { (2015). }\end{array}$ \\
\hline $\begin{array}{l}\text { Clinical study of } \\
\text { transcutaneous } \\
\text { influenza vaccination } \\
\text { using a dissolving } \\
\text { microneedle patch. }\end{array}$ & $\begin{array}{l}\text { Microneedles of hyaluronic acid } \\
\text { with hemagglutinins of } \\
\text { influenza for vaccination, } \\
\text { inducing a strong immune } \\
\text { response. }\end{array}$ & $\begin{array}{l}\text { Hirobe et } \\
\text { al. (2015). }\end{array}$ \\
\hline $\begin{array}{l}\text { Potential of hydrogel- } \\
\text { forming and } \\
\text { dissolving } \\
\text { microneedles for use } \\
\text { in paediatric } \\
\text { populations. }\end{array}$ & $\begin{array}{l}\text { Application of biodegradable } \\
\text { microneedles allows continuous } \\
\text { delivery of caffeine into } \\
\text { systemic circulation, } \\
\text { maintaining the therapeutic } \\
\text { concentration for more than } \\
24 \mathrm{~h} \text {. Microneedles are a viable } \\
\text { alternative for paediatric } \\
\text { administration. }\end{array}$ & $\begin{array}{l}\text { Caffarel- } \\
\text { Salvador et } \\
\text { al. (2015). }\end{array}$ \\
\hline
\end{tabular}




\begin{tabular}{|c|c|c|}
\hline $\begin{array}{l}\text { Silicon microneedles } \\
\text { for deep brain drug } \\
\text { infusion. }\end{array}$ & $\begin{array}{l}\text { Microarray prepared on silicon } \\
\text { for infusion of drugs in the brain } \\
\text { to identify connections and } \\
\text { neuronal activities. Using glass } \\
\text { cover on silicon technology } \\
\text { (GCoS), a microneedle designed } \\
\text { for drug infusion was } \\
\text { successfully implemented in } \\
\text { small animals with point- } \\
\text { targeting accuracy and less } \\
\text { damage in the experiments. }\end{array}$ & $\begin{array}{l}\text { Lee et al. } \\
(2015) .\end{array}$ \\
\hline $\begin{array}{l}\text { Nitrogen- } \\
\text { incorporated } \\
\text { ultrananocrystalline } \\
\text { diamond microneedle } \\
\text { arrays for } \\
\text { electrochemical } \\
\text { biosensing. }\end{array}$ & $\begin{array}{l}\text { Nitrogen-incorporated ultra- } \\
\text { crystalline diamond-coated } \\
\text { titanium alloy microneedle } \\
\text { arrays can detect } \\
\text { electrochemical signals } \\
\text { (dopamine and uric acid). }\end{array}$ & $\begin{array}{l}\text { Skoog et al. } \\
\text { (2015). }\end{array}$ \\
\hline $\begin{array}{l}\text { Fenestrated } \\
\text { microneedles for } \\
\text { ocular drug delivery. }\end{array}$ & $\begin{array}{l}\text { The researchers developed } \\
\text { fenestrated microneedles } \\
\text { (lengths } 500-1500 \mu \mathrm{m} \text { ), which } \\
\text { serve as reservoirs for passive } \\
\text { delivery. The capacity of these } \\
\text { microneedles can be up to five } \\
\text { times more than that of solid } \\
\text { microneedles. }\end{array}$ & $\begin{array}{l}\text { Omid et al. } \\
2016 .\end{array}$ \\
\hline
\end{tabular}




\begin{tabular}{|c|c|c|}
\hline $\begin{array}{l}\text { A microneedle } \\
\text { electrode array on } \\
\text { flexible substrate for } \\
\text { long-term } \\
\text { electroencephalogram } \\
\text { (EEG) monitoring. }\end{array}$ & $\begin{array}{l}\text { The use of microneedles } \\
\text { (silicone height of } 190 \mu \mathrm{m} \text { ) } \\
\text { capable of EEG monitoring. } \\
\text { Microneedles can be adapted to } \\
\text { the skin providing robust } \\
\text { contact with the skin }\end{array}$ & $\begin{array}{l}\text { Renxin et } \\
\text { al. } 2017 \text {. }\end{array}$ \\
\hline $\begin{array}{l}\text { Transfer-moulded } \\
\text { wrappable } \\
\text { Microneedle Meshes } \\
\text { for Perivascular Drug } \\
\text { Delivery. }\end{array}$ & $\begin{array}{l}\text { Developed a wrappable } \\
\text { microneedle mesh of poly } \\
\text { (lactic-co-glycolic acid) (height } \\
\text { of } 640 \mu \mathrm{m} \text { ) to deliver the anti- } \\
\text { proliferative drug into an } \\
\text { injured blood vessel for IH } \\
\text { reduction with minimal } \\
\text { mechanical stress. }\end{array}$ & $\begin{array}{l}\text { Lee et al. } \\
\text { (2017). }\end{array}$ \\
\hline $\begin{array}{l}\text { Microneedle array } \\
\text { electrodes for } \\
\text { continuous glucose } \\
\text { monitoring sensors. }\end{array}$ & $\begin{array}{l}\text { The use of microneedles } \\
\text { eliminates the interference } \\
\text { involved in the detection of } \\
\text { glucose in comparison with } \\
\text { other glucose detection devices. }\end{array}$ & $\begin{array}{l}\text { Sanjiv et al. } \\
\text { (2017). }\end{array}$ \\
\hline $\begin{array}{l}\text { Anti-obesity effect of } \\
\text { a caffeine-loaded } \\
\text { microneedle patch. }\end{array}$ & $\begin{array}{l}\text { Microneedles of PVP, PVP and } \\
\text { PVA ( } 500 \mu \mathrm{m} \text { long) loaded with } \\
\text { caffeine, has a weight loss of } \\
12.8 \pm 0.75 \% \text { in obese C } 57 \mathrm{BL} / 6 \mathrm{~J} \\
\text { mice. }\end{array}$ & $\begin{array}{l}\text { Manita et } \\
\text { al. (2017). }\end{array}$ \\
\hline
\end{tabular}




\begin{tabular}{|c|c|c|}
\hline $\begin{array}{l}\text { A boosting skin } \\
\text { vaccination with } \\
\text { dissolving } \\
\text { microneedle patch } \\
\text { encapsulating M2e } \\
\text { vaccine broadens the } \\
\text { protective efficacy of } \\
\text { conventional } \\
\text { influenza vaccines. }\end{array}$ & $\begin{array}{l}\text { The results of this study } \\
\text { demonstrate that receiving } \\
\text { 4M2etFliC microneedles of } \\
\text { carboxymethyl cellulose boosts } \\
\text { immunisation after the } \\
\text { conventional influenza vaccine. } \\
\text { The array has } 100 \text { microneedles } \\
\text { ( } 250 \text { and } 650 \mu \mathrm{m} \text {, diameter and } \\
\text { length, respectively). }\end{array}$ & $\begin{array}{l}\text { Zhu et al. } \\
\text { (2017). }\end{array}$ \\
\hline $\begin{array}{l}\text { Chitosan } \\
\text { microneedles patch to } \\
\text { enhancing } \\
\text { immunogenicity of } \\
\text { antigens. }\end{array}$ & $\begin{array}{l}\text { A strong and persistent } \\
\text { antibody responses for at least } \\
18 \text { weeks by microneedles } \\
\text { loaded with OVA and resulted in } \\
\text { at least a } 2.5 \text {-fold antigen dose } \\
\text { reduction. }\end{array}$ & $\begin{array}{l}\text { Chen et al. } \\
(2018) \text {. }\end{array}$ \\
\hline $\begin{array}{l}\text { Microneedles of } \\
\text { alginate and } \\
\text { hyaluronate for } \\
\text { transdermal delivery } \\
\text { of insulin. }\end{array}$ & $\begin{array}{l}\text { Microneedles }(650 \mu \mathrm{m}) \text { patches } \\
\text { made with alginate and } \\
\text { hyaluronate loaded with insulin. } \\
\text { The relative pharmacologic } \\
\text { availability and relative } \\
\text { bioavailability of insulin from } \\
\text { microneedle were } 90.5 \pm 6.8 \% \\
\text { and } 92.9 \pm 7 \% \text { in mice. }\end{array}$ & $\begin{array}{l}\text { Yu et al. } \\
\text { (2017). }\end{array}$ \\
\hline
\end{tabular}




\section{Microneedle for \\ Development of microneedles to \\ Dae et al. \\ minimally invasive obtain biochemical information (2018). and painless blood sampling. (1.8 mm, an inner diameter of $60 \mu \mathrm{m}$, an outer tip of $100 \mu \mathrm{m}$ and a $60^{\circ}$ bevel angle), that can extract blood volumes up to 840 $\mu \mathrm{L}$. \\ Microneedle with charge reversal $\mathrm{pH}-$ sensitive copolymers improve antigen presenting cells- homing DNA vaccine delivery and immune responses. \\ Microneedles with charge reversal copolymer that can stimulate the CD4+ and CD8+ T cell immunity. In vivo demonstrated the delivery of a DNA vaccine encoding $A \beta$ fusion protein to antigen present cells induced a robust antigen-specific immune response.}

Table 3: Table detailing studies and the outcomes of studies done on how microneedles have been applied using various techniques (Serrano-Castañeda et al., 2018).

\section{Clinical trials and safety}

In 2001, the first clinical study was conducted by Kaushik et al., it aimed at exploring the possibility of whether silicon microneedles were small enough to prevent pain compared to a 26-gauge hypodermic needle (Kaushik et al., 2001). In the study, 12 healthy male and female volunteers were selected, and microneedles were applied to their forearms. It was concluded that nerve endings were less stimulated compared to hypodermic needles, thus less pain was experienced.

As microneedle technology is advancing, many clinical trials are being done to reduce the disadvantages of microneedles used commercially. Arya et al. (2017) conducted a 15 -subject human trial to determine whether microneedles cause local skin reactions. 
The result of the study demonstrated that microneedles did not cause any swelling, pain or erythema at the site of application of the patch. More so, patients could selfadminister the patches by hand without assistance from a clinician (Arya et al., 2017).

In 2016, a randomised clinical trial was conducted on 21 men to investigate the enhanced delivery of lidocaine after pre-treatment with microneedles. Using topical 4 per cent lidocaine cream, it was observed that, without the microneedle pretreatment, anaesthesia was produced after $60 \mathrm{~min}$; however, with the microneedle pre-treatment, anaesthesia occurred within 30 min (Ornelas et al., 2016). Another open trial was conducted on ten patients in 2018 for hyaluronic acid-based microneedle patch to investigate the therapeutic effects to treat psoriasis. In the study, Calcipotriol-betamethasone ointment was applied on the skin and a microneedle patch was applied over this once every day for a week. The result showed that within one week of application, there was significant reduction in psoriatic plaques and thus was found efficient compared to the conventional cream application (Lee et al., 2018)

\section{Current research, advances, challenges and future trends}

Previous studies done to observe the efficiency of drug delivery using microneedles showed that (initially on cadavers) large molecules such as albumin and insulin can pass through the skin (Bora et al., 2008). This was later confirmed by further studies (Donnelly et al., 2014, Ita, 2015). Currently, many new innovative microneedle concepts are being researched for better microneedle production and clinical uses (Serrano et al., 2014, Hirobe et al., 2015, Ma et al., 2015, Yu et al. 2017).

While studies have shown efficacy of microneedles, the main problems associated with this technology remains skin allergy, redness and irritation. This limits the concentration of drug that can be loaded into the microneedle. Also, passing hydrophilic and large compounds through the skin is still a major challenge. Selection of the right material needs to be taken into consideration in the fabrication of these needles; this includes the material that have adequate mechanical strength and insertion force. The main aim of this being the ability to increase the permeability of drugs using microneedles without stimulating nerve endings. While some microneedles can be attached by patients without clinician assistance, there is a chance of infection if the skin pores do not close properly after application (Ita, 2015). 
The 3M's hollow microneedle technology is an advancing technology in which microneedles are flexible enough and can be used to administer a few hundreds of milligrams of proteins that go directly into the systemic circulation (Burton, 2011). Furthermore, an emerging technique in which a combination of ultrasound and transdermal drug delivery is used to increase drug permeability is observed in a study done by Han and Das in 2015. Hence, microneedles can be fabricated with a variety of modifications in order to smartly deliver the drug through the skin, providing a new direction and revolution in the field of transdermal drug delivery systems.

\section{Approved products}

The first microneedle product which was commercially approved was Dermaroller. Although many microneedle products are yet to gain market authorisation for medical and cosmetic use, there are some already on the market. Companies in US, Europe and Japan are selling microneedle products, and some of them are listed below.

\begin{tabular}{|c|c|c|c|}
\hline Product name & $\begin{array}{l}\text { Company } \\
\text { name }\end{array}$ & $\begin{array}{l}\text { Description of } \\
\text { the product }\end{array}$ & Use \\
\hline Dermaroller ${ }^{\circledR}$ & $\begin{array}{l}\text { Dermaroller }{ }^{\circledR} \\
\text { Germany, } \\
\text { White Lotus }\end{array}$ & $\begin{array}{l}\text { A cylindrical } \\
\text { roller with } \\
\text { solid or metal } \\
\text { microneedles, } \\
0.2-2.5 \mathrm{~mm} \text { in } \\
\text { length }\end{array}$ & $\begin{array}{l}\text { Improve skin } \\
\text { texture, } \\
\text { treat scars and } \\
\text { hyperpigmentation }\end{array}$ \\
\hline $\begin{array}{l}\text { C-8 (Cosmetic } \\
\text { type) }\end{array}$ & $\begin{array}{l}\text { Dermaroller }{ }^{\circledR} \\
\text { Germany, } \\
\text { White Lotus }\end{array}$ & $\begin{array}{l}\text { A needle } \\
\text { length of only } \\
0.13 \mathrm{~mm}(130 \\
\mu \mathrm{m})\end{array}$ & $\begin{array}{l}\text { Used to enhance } \\
\text { penetration of } \\
\text { topical agents }\end{array}$ \\
\hline $\begin{array}{l}\text { CIT-8 (Collagen } \\
\text { Induction } \\
\text { Therapy) }\end{array}$ & $\begin{array}{l}\text { Dermaroller }{ }^{\circledR} \\
\text { Germany, } \\
\text { White Lotus }\end{array}$ & $\begin{array}{l}\text { A needle } \\
\text { length of } 0.5 \\
\mathrm{~mm}(500 \mu \mathrm{m})\end{array}$ & $\begin{array}{l}\text { Used in collagen } \\
\text { induction and skin } \\
\text { remodelling }\end{array}$ \\
\hline
\end{tabular}




\begin{tabular}{|c|c|c|c|}
\hline Product name & $\begin{array}{l}\text { Company } \\
\text { name }\end{array}$ & $\begin{array}{l}\text { Description of } \\
\text { the product }\end{array}$ & Use \\
\hline MF-8 type & $\begin{array}{l}\text { Dermaroller }{ }^{\circledR} \\
\text { Germany, } \\
\text { White Lotus }\end{array}$ & $\begin{array}{l}\text { A needle } \\
\text { length of } 1.5 \\
\mathrm{~mm}(1500 \mu \mathrm{m})\end{array}$ & Treats scars \\
\hline MS-4 & $\begin{array}{l}\text { Dermaroller }{ }^{\circledR} \\
\text { Germany, } \\
\text { White Lotus }\end{array}$ & $\begin{array}{l}\text { A small } \\
\text { cylinder, } 1 \mathrm{~cm} \\
\text { length, } 2 \mathrm{~cm} \\
\text { diameter, and } \\
\text { four circular } \\
\text { arrays of } \\
\text { needles which } \\
\text { are } 1.5 \mathrm{~mm} \text { in } \\
\text { length }\end{array}$ & $\begin{array}{l}\text { Used on facial acne } \\
\text { scars }\end{array}$ \\
\hline MicroHyala ${ }^{\circledR}$ & $\begin{array}{l}\text { CosMed } \\
\text { transdermal } \\
\text { drug delivery }\end{array}$ & $\begin{array}{l}\text { Dissolving } \\
\text { microneedle } \\
\text { patch with } \\
\text { hyaluronic } \\
\text { acid }\end{array}$ & Wrinkle treatment \\
\hline LiteClear ${ }^{\circledR}$ & $\begin{array}{l}\text { Nanomed } \\
\text { skincare }\end{array}$ & $\begin{array}{l}\text { Solid silicon } \\
\text { microneedles } \\
\text { are used as } \\
\text { pre-treatment } \\
\text { and then drug } \\
\text { applied } \\
\text { topically }\end{array}$ & $\begin{array}{l}\text { Treats acne and } \\
\text { skin blemishes }\end{array}$ \\
\hline
\end{tabular}




\begin{tabular}{|c|c|c|c|}
\hline Product name & $\begin{array}{c}\text { Company } \\
\text { name }\end{array}$ & $\begin{array}{l}\text { Description of } \\
\text { the product }\end{array}$ & Use \\
\hline Soluvia ${ }^{\circledR}$ & $\begin{array}{l}\text { Sanofi } \\
\text { Pasteur } \\
\text { Europe }\end{array}$ & $\begin{array}{l}\text { Hollow } \\
\text { microneedle } \\
\text { attached to a } \\
\text { syringe }\end{array}$ & $\begin{array}{l}\text { Influenza } \\
\text { vaccination }\end{array}$ \\
\hline h-patch & Valeritas & $\begin{array}{l}\text { Small } \\
\text { adhesive } \\
\text { machine-like } \\
\text { patch is used }\end{array}$ & $\begin{array}{l}\text { To deliver drugs in } \\
\text { subcutaneous } \\
\text { tissue(insulin) }\end{array}$ \\
\hline $\begin{array}{l}\text { Microstructured } \\
\text { transdermal } \\
\text { system }\end{array}$ & $3 \mathrm{M}$ & $\begin{array}{l}\text { Hollow } \\
\text { microneedle }\end{array}$ & $\begin{array}{l}\text { To deliver } \\
\text { biologics and other } \\
\text { small molecules }\end{array}$ \\
\hline
\end{tabular}

Table 4: Approved microneedle products (Directly adapted from Waghule et al., 2019, Bora et al., 2008, Li et al., 2017, Singh and Yadav, 2016).

\section{Conclusion}

This paper has highlighted some of the main frontiers in the use of microneedles as an important modern technique in percutaneous drug delivery. The advances in microfabrication technology and scalability in a configuration of multi-arrays have ensured that this technology will further observe progress in the coming years.

Other drug delivery methods, such as oral administration, are limited in terms of low surface absorption area and reduced enzymatic degradation due to first-pass metabolism. Thus, the advent of the microneedle has been a needed alternative to these challenges for optimum systemic delivery of a drug.

Microneedles allow painless insertion with minimum tissue damage, better control over the dosage of the drug, does not generate infectious waste and patients are more compliant in using microneedles. Consequently, microneedles have been growing in the fields of drug development, therapeutics and cosmetology. It is possible to 
administer peptides, avoiding multiple daily injections in the case of insulin. In addition, the use of microneedles is growing in medicine. They are being used in the diagnosis and treatment of glaucoma and in monitoring bio-signals. Finally, the use of microneedles has been shown to be very useful for the treatment of alopecia, antiageing and scars. Due to all the advantages and alternatives that the use of microneedles offers, there has been an increase in research on their applications in fields such as healthcare, medicine and even cosmetics.

However, some challenges regarding the use of these microneedles in regard to safety issues have also been discussed. More so, there are concerns regarding the cost of the delivery system, delayed onset of action and possible misuse, accidental use, or abuse (Caffarel-Salvador et al., 2015). While trials have shown that there is no risk of infection on the patient population, there is a need to further investigate skin pore closure after microneedle application in a larger population group. It is also essential to ensure that materials used for microneedle fabrication do not induce skin irritation. Until now, only very few pharmaceutical microneedle products have been granted market authorisation (Table 4) as safety and efficacy are paramount in the quest for market authorisation. Problems may arise when microneedles are frequently applied in the same site of administration. Also, if the same dose is applied at different sites of administration, systemic bioavailability may be affected; and lead to bioavailability variation.

Despite the above-mentioned limitations, current advances in the development of these devices are promising and forthcoming. While there needs to be even more work done before microneedles become routine drug delivery systems in clinical practice, the trajectory of research suggests that there will be further advances in the microneedle technology. The commercial viability of microneedles is a gap in the literature that needs to be addressed. This is to allow for industrial scale manufacture. Multiple techniques discussed in this literature review (Table 1) are known to be laborious and involve the use of non-FDA-approved excipients such as silicon (Cheung et al., 2016). However, there is an exponential trend in the research done on microneedle technology. There is also an increasing trajectory in the use of microneedles for commercial scale products. From the current literature, the upward trend observed in the number of publications is unlikely to change in the next decade due to continuous advances in this technology. Thus, the more research output generated on this technology (from more publications), the more data there is to improve microneedle technology. Furthermore, extrapolation of data using 'time series analysis' allows adequate prediction of trends in the number of journal papers 
that would be published regarding microneedle technology. This analysis suggests that there would be observable and significant growth in the field of microneedles in coming years. Microneedles are a crucial technology for medical and pharmaceutical applications, and growth in this technology will be observed in the coming decades.

\section{List of figures}

Figure 1: The nerve stimulation and needle length of a hypodermic medication compared to microneedles (MyLifesspan.com. 2018).

Figure 2: Different types of microneedles and their release mechanisms (Yeu et al., 2012).

Figure 3: Structure of the human skin showing the three layers of the skin (BCcampus Open Education. 2018).

Figure 4.1: Micrograph of the upper dermis and epidermis showing the layers and major cell types (Directly adapted from Wickett and Visscher, 2006).

Figure 5: The corneocyte envelope as proposed by Steinert (Adapted from Steinert et al., 1995).

Figure 6: Schematic representation of the chemical structure of ceramides (Adapted from Wickett and Visscher, 2006).

Figure 7: Normal lipid lamella at the third tape strip (magnification, 3,200,000) (Adapted from Wickett and Visscher, 2006).

\section{List of tables}

Table 1: Fabrication techniques for different types of microneedles (Pérennès et al., 2006; Yoon et al., 2006; Migdadi et al., 2018; Adapted from Waghule et al., 2019).

Table 2: Table detailing information regarding the advantages and disadvantages of microneedles (adapted from Serrano-Castañeda et al., 2018; Ogundele and Okafor, 2017).

Table 3: Table detailing studies and outcomes of studies done on how microneedles have been applied in various techniques (Serrano-Castañeda et al., 2018). 
Table 4: Approved microneedle products (Directly adapted from Waghule et al., 2019, Bora et al., 2008, Li et al., 2017, Singh et al., 2016).

\section{References}

Alexander, A., A. Dwivedi, A. Ajazuddin, T. Giri, S. Saraf, S. Saraf and D. Tripathi (2012), 'Approaches for breaking the barriers of drug permeation through transdermal drug delivery', J Control Release, 164, 26-40

Arya, J., S. Henry, H. Kalluri, D. V. McAllister, W. P. Pewin and M. R. Prausnitz (2017), 'Tolerability, usability and acceptability of dissolving microneedle patch administration in human subjects', Biomaterials, 128, 1-7

BCcampus Open Education (2018), 'The integumentary system. layers of the skin', available at https://opentextbc.ca/anatomyandphysiology/chapter/5-1-layers-ofthe-skin/ accessed 20 March 18

Birchall, J. C. (2006), 'Microneedle array technology: The time is right but is the science ready?', Expert Rev Med Devices, 3, 1-4

Bora, P., L. Kumar and A. Bansal (2008), 'Microneedle technology for advanced drug delivery: Evolving vistas', Curr. Res. Inf. Pharm. Sci., 9

Burton, S. A., C. Y. Ng, R. Simmers, C. Moeckly, D. Brandwein, T. Gilbert, N. Johnson, K. Brown, T. Alston, G. Prochnow, K. Siebenaler and K. Hansen (2011), 'Rapid intradermal delivery of liquid formulations using a hollow microstructured array', Pharm. Res., 28 (1), 31-40

Caffarel-Salvador, E., T. M. Tuan-Mahmood, J. C. McElnay H. O. McCarthy, K. Mooney, A. D. Woolfson and R. F. Donnelly (2015), 'Potential of hydrogel-forming and dissolving microneedles for use in paediatric populations', Int J Pharm, 489 (1-2), 158-69

Chen M. C, K. Lai, M. Ling and C. W. Lin (2018) 'Enhancing immunogenicity of antigens through sustained intradermal delivery using chitosan microneedles with a patch-dissolvable design', Acta Biomater, 65, 66-75

Chua, B., S. P. Desai, M. J. Tierney, J. A. Tamada, and A. N. Jina (2013), ‘Effect of microneedles shape on skin penetration and minimally invasive continuous glucose monitoring in vivo', Sensors and Actuators, A: Physical, 203, 373-81. 
Cheung, K. and D. B. Das (2016), 'Microneedles for drug delivery: Trends and progress', Drug Delivery, 23 (7), 2338-54

Dae, L., G. Cheng and I. Chunhwa (2018), 'A three-dimensional and bevel-angled ultrahigh aspect ratio microneedle for minimally invasive and painless blood sampling', Sensors and Actuators B, 255, 384-90

Donnelly, R., M. Garland, D. Morrow, K. Migalska, T. Sing, R. Majithiya and D. Woolfson (2010), 'Optical coherence tomography is a valuable tool in the study of the effects of microneedle geometry on skin penetration characteristics and in skin dissolution', J Control Release, 147, 333-41

Donnelly, R. F., M. T. C. McCrudden, A. Z. Alkilani, E. Larrañeta, E. McAlister, A. J. Courtenay, M.-C. Kearney, T. R. Raj Singh, H. O. McCarthy, V. L. Kett, V. L. et al. (2014), 'Hydrogel-forming microneedles prepared from “super swelling” polymers combined with lyophilised wafers for transdermal drug delivery', PLoS ONE, 9, e111547

Escobar-Chávez, J. J., D. Bonilla-Martínez, M. A. Villegas-González, E. MolinaTrinidad, N. Casas-Alancaster and A. L. Revilla-Vázquez (2011) 'Microneedles: A valuable physical enhancer to increase transdermal drug delivery', Journal of Clinical Pharmacology, 51, 964-77

Forvi, E., M. Bedoni., R. Carabalona, M. Soncini, P. Mazzoleni, F. Rizzo, C. O’Mahony, C. Morasso, G. Cassarà and F. Gramatica (2012), 'Preliminary technological assessment of microneedles-based dry electrodes for biopotential monitoring in clinical examinations', Sensor Actuat A-Phys, 180, 177-86

Gill, H. S. and M. R. Prausnitz (2008), 'Pocketed microneedles for drug delivery to the skin', J Phys Chem Solids, 69 (5-6), 1537-41

Gomma, Y., M. Garland, F. McInnes , L. El-Khordagui, C. Wilson and R. Donnelly (2012), 'Laser-engineered dissolving microneedles for active transdermal delivery of nadroparin calcium', Eur J Pharm Biopharm, 82 (2), 299-307

Han, T. and D. B. Das (2015), 'Potential of combined ultrasound and microneedles for enhanced transdermal drug permeation: A review’, Eur. J. Pharm. Biopharm., 89, $312-28$ 
Henry S., D. V. McAllister, M. G. Allen and M. R. Prausnitz (1998), 'Microfabricated microneedles: A novel approach to transdermal drug delivery', Journal of Pharmaceutical Science, 87, 922-25

Hiraishi, Y., S. Nandakumar, S. O. Choi, J. W. Lee, Y. C. Kim, J. E. Posey, S. B. Sable and M. R. Prausnitz (2011), 'Bacillus Calmette-Guérin vaccination using a microneedle patch', Vaccine, 29 (14), 2626-36

Hirobe, S., H. Azukizawa, T. Hanafusa, K. Matsuo, Y. Quan, F. Kamiyama, I. Katayama, N. Okada and S. Nakagawa, (2015), 'Clinical study and stability assessment of a novel transcutaneous influenza vaccination using a dissolving microneedle patch', Biomaterials, 57, 50-58

Huu, D., W. Nak, T. Thavasyappan, V. H. Giang. L. Min, Y. Yue, J. Ji and S. Doo (2018), 'Microneedle arrays coated with charge reversal $\mathrm{pH}$-sensitive copolymers improve antigen presenting cells-homing DNA vaccine delivery and immune responses', $J$. Control. Release, 269, 225-34

Indermun, S., R. Luttge, Y. Choonara, P. Kumar, L. du Toit, G. Modi and V. Pillay, (2014), 'Current advances in the fabrication of microneedles for transdermal delivery', J Control Release, 185, 130-38

Ita, K. (2015), 'Transdermal delivery of drugs with microneedles-Potential and challenges', Pharmaceutics, 7 (3), 90-105

Jacoby, E, C. Jarrahian, H. F. Hull and D. Zehrung (2015), 'Opportunities and challenges in delivering influenza vaccine by microneedle patch', Vaccine, 33, 4699-704

Jepps, O.G., Y. Dancik, Y. G. Anissimov and M. S. Roberts (2013), 'Modeling the human skin barrier - Towards a better understanding of dermal absorption', Advanced Drug Delivery Reviews, 65 (2), 152-68

Kaushik, S., H. H. Allen, D. D. Donald, D. V. McAllister, S. Smitra, M. G. Allen and M. R. Prausnitz (2001), 'Lack of pain associated with microfabricated microneedles', Anesthesia \& Analgesia, 92, 502-04

Khanna, P., J. A. Strom, J. I. Malone and S. Bhansali, (2008), 'Microneedle-based automated therapy for diabetes mellitus', Journal of Diabetes Science and 
Technology, 2 (6), Available at: https://doi.org/10.1177/193229680800200621. Accessed 29 Oct 2019

Kim, J. D., M. Kim, H. Yang, K. Lee and H. Jung (2013), 'Droplet-born air blowing: Novel dissolving microneedle fabrication', J Control Release, 170, 430-36

Kim, Y. C., J. H. Park and M. R. Prausnitz (2012), 'Microneedles for drug and vaccine delivery', Advanced Drug Delivery Reviews 64 (14), 1547-68

Kim, Y. C., H. Edelhauser and M. R. Prausnitz (2014), 'Targeted delivery of antiglaucoma drugs to the supraciliary space using microneedle', Invest Ophthalmol Vis Sci. 55 (11), 7387-97

Kolarsick, P. A. J., M. A. Kolarsick and C. Goodwin, (2011), 'Anatomy and physiology of the skin', Journal of the Dermatology Nurses' Association, 3 (4), 203-13

Lanke, S. S. S., C. S. Kolli, J. G. Stroma and A. K. Banga (2009), 'Enhanced transdermal delivery of low molecular weight heparin by barrier perturbation', International Journal of Pharmaceutical, 365 (1-2), 26-33

Larrañeta, E., R. E. M. Lutton, A. D. Woolfson and R. F. Donnelly (2016), 'Microneedle arrays as transdermal and intradermal drug delivery systems: Materials science, manufacture and commercial development', Mater. Sci. Eng. R Rep., 104, 1-32

Lee, J. H., Y. S. Jung, G. M. Kim and J. M. Bae (2018), A hyaluronic acid-based microneedle patch to treat psoriatic plaques: A pilot open trial', Br. J. Dermatol., 178 (1), e24-e25

Lee, J. Y., D. H. Kim, K. J. Lee, I. H. Seo, S. H. Park, E. H. Jang, Y. Park, Y.-N. Youn and W. Ryu (2017), 'Transfer-molded wrappable microneedle meshes for perivascular drug delivery', J. Control. Release, 268, 237-46

Lee, K.-S., R. H. Kim, D.-Y. Yang and S. H. Park (2008), 'Advances in 3D nano/microfabrication using two-photon initiated polymerization', Polymer Science, 33, 631-81

Lee, H. J., Y. Son, D. Kim, K. Kyung Kim, N. Choi, E.-S. Yoon and I. Cho (2015), 'A new thin silicon microneedle with an embedded microchannel for deep brain drug infusion', Sensor Actuat B-Chem, 209, 413-22

Lever, W. F. (1949), 'Histopathology of the skin', Dermatology, 449 
Levin, Y., E. Kochba, R. Kenney (2014), 'Clinical evaluation of a novel microneedle device for intradermal delivery of an influenza vaccine: Are all delivery methods the same?', Vaccine 32, 4249-52.

Li, J., M. Zeng, H. Shan and C. Tong (2017), 'Microneedle patches as drug and vaccine delivery platform', Curr. Med. Chem., 24 (22), 2413-22

Manita, D., K. Suyong, G. Cheng, F. Shayan, J. Mingyu, M. Yonghao, H. Inyoung and J. Hyungil, (2017), 'Anti-obesity effect of a novel caffeine-loaded dissolving microneedle patch in high-fat diet-induced obese C57BL/6J mice', J. Control. Release, 265, 41-47

Matsuo, K., Y. Yokota, Y. Zhai, Y. Quan, F. Kamiyama, Y. Mukai, N. Okada and S. Nakagawa (2002), 'A low invasive and effective transcutaneous immunization system using a novel dissolving microneedle array for soluble and particulate antigens', J Control Release, 161, 10-17

Migdadi, E. M., A. J. Courtenay, I. A. Tekko, M. T. C. McCrudden, M.-C. Kearney, E. McAlister, H. O. McCarthy and R. F. Donnelly (2018), 'Hydrogel-forming microneedles enhance transdermal delivery of metformin hydrochloride', $J$. Control. Release, 285, 142-51

Mikszta, J., J. Alarcon, J. Brittingham, D. Sutter, R. Pettis and N. Harvey (2002), 'Improved genetic immunization via micromechanical disruption of skin-barrier function and targeted epidermal delivery', Nat Med, 8, 415-19

MyLifesspan.com (2018), available at http://my-lifespan.com/news-144.html, accessed 20 March 18

Narayanan S. P. and S. Raghavan (2018), 'Fabrication and characterization of goldcoated solid silicon microneedles with improved biocompatibility', Int. J. Adv. Manuf. Technol. 1-7

Ogundele, M. and H. Okafor (2017), 'Transdermal drug delivery: Microneedles, their fabrication, and current trends in delivery methods', Journal of Pharmaceutical Research International, 18 (5), 1-14

Omid, K., Y. Malik, and P. Masaru (2016), 'Fenestrated microneedles for ocular drug delivery', Sensors and Actuators B: Chemical, 223, 15-23 
Ornelas, J. N. Foolad, V. Shi, W. Burney and R. K. Sivamani (2016), 'Effect of microneedle pretreatment on topical anesthesia: A randomized clinical trial', JAMA Dermatol., 152 (4), 476-77

Patil P. M., P. D. Chaudhari, J. K Patel, K. A. Kedar and P. P. Katolkar (2012), 'Recent trends in challenges and opportunities of transdermal drug delivery system', Int. J. Drug Dev. \& Res., 4 (1), 39-50

Pérennès. F., B. Marmiroli, M. Matteucci, M. Tormen, L. Vaccari and E. D. Fabrizio (2006), 'Sharp beveled tip hollow microneedle arrays fabricated by LIGA and 3D soft lithography with polyvinyl alcohol', J. Micromech. Microeng., 16, 473-79

Renxin, W., J. Xiaoming and Z. WeiWang (2017), 'A microneedle electrode array on flexible substrate for long-term EEG monitoring', Sensors and Actuators B., 244, $750-58$

Ripolin, A., J. Quinn, E. Larrañeta, E. M. Vicente-Perez, J. Barry and R. F..Donnelly, (2017) 'Successful application of large microneedle patches by human volunteers', International Journal of Pharmaceutics, 521 (1-2), 92-101

Sharma, S., E. Takagi, T. Cass, W. Tsugawa and K. Sode (2017), 'Minimally invasive microneedle array electrodes employing direct electron transfer type glucose dehydrogenase for the development of continuous glucose monitoring sensors', Procedia Technology, 27, 208-09

Scott, I. R., C. R. Harding, and J. G. Barrett (1982), 'Histidine-rich protein of the keratohyalin granules: Source of the free amino acids, urocanic acid and pyrrolidone carboxylic acid in the stratum corneum', BiochimBiophys Acta, 719, 110-07

Serrano-Castañeda, P. (2014), Development and characterization of a transdermal patch of pravastatin coupled amicroagujas as a physical promoter of transdermal penetration', unpublished MasterThesis, Mexico D.F: UAMXochimilco

Serrano-Castañeda, P., J. J. Escobar-Chávez, I. M. Rodríguez-Cruz, L. M. MelgozaContreras and J. Martínez-Hernández (2018), 'Microneedles as enhancer of drug absorption through the skin and applications in medicine and cosmetology', $J$ Pharm Pharm Sci, 21, 73-93 
Sharma, D. (2017), 'Microneedles: An approach in transdermal drug delivery, A review', PharmaTutor, 6(1), 7-15

Singh, A. and S. Yadav (2016), 'Microneedling: advances and widening horizons', Indian Dermatol. Online J., 7 (4) 244-54

Skoog, S., P. Miller, R. Boehm, A. Sumant, R. Polsky and R. Narayan (2015), 'Nitrogenincorporated ultrananocrystalline diamond microneedle arrays for electrochemical biosensing’, Diam Relat Mater, 54, 39-46

Steinert, P. M. and L. N. Marekov (1995), 'The proteins elafin, filaggrin, keratinintermediate filaments, loricrin, and small proline-rich proteins 1 and 2 are isodipeptide cross-linked components of the human epidermal cornified cell envelope', J Biol Chem, 270, 17702-11

Uddin, M. J., N. Scoutaris, P. Klepetsanis, B. Chowdhry, M. R. Prausnitz and D. Douroumis (2015), 'Inkjet printing of transdermal microneedles for the delivery of anticancer agents', Int. J. Pharm., 494 (2), 593-602

Van Damme, P., F. Oosterhuis-Kafeja, M. van der Wielen, Y. Almagor, O. Sharon and Y. Levin (2009), 'Safety and efficacy of a novel microneedle device for dose sparing intradermal influenza vaccination in healthy adults', Vaccine, 27 (3), 454-59.

Vemulapalli, V., Y. Yang, P. M. Friden and A. K. Banga (2008), 'Synergistic effect of iontophoresis and soluble microneedles for transdermal delivery of methotrexate', Journal of Pharmaceutical Pharmacology, 60 (1), 27-33

Vrdoljak, A., M. McGrath, J. Carey, S. Draper, A. Hill, C. O’Mahony, A. Crean and A. Moore (2012), 'Coated microneedle arrays for transcutaneous delivery of live virus vaccines', J Control Release, 159, 34-42

Waghule, T., G. Singhvi, S. Kumar and D. Murali (2019), 'Microneedles: A smart approach and increasing potential for transdermal drug delivery system', Biomedicine \& Pharmacotherapy, 109, 1249-58

Wang, P. M., M. Cornwell, J. Hill, M. R. Prausnitz (2006), 'Precise microinjection into skin using hollow microneedles', Journal of Investigative Dermatology, 126 (5) 1080-87.

Wermeling, D.P., S. L. Banks, D. A. Hudson, H. S. Gill, J. Gupta, M. R. Prausnitz and A. L. Stinchcomb (2008), 'Microneedles permit transdermal delivery of a skin- 
impermeant medication to humans', Proceedings of the National Academy of

Sciences of the United States of America, 105 (6) 2058-63

Wickett, R. R. and M. O. Visscher (2006), 'Structure and function of the epidermal barrier’, American Journal of Infection Control, 34 (10), S98-110

Williams, A. C. and B. W. Barry (2004), 'Penetration enhancers', Adv. Drug Deliv. Rev., 56 (5) 603-18

World Health Organization (2009), 'WHO guidelines on hand hygiene in health care:

First global patient safety challenge clean care is safer care', available at https://www.ncbi.nlm.nih.gov/books/NBK144027/ accessed on 11/10/2017

Wu, Y. (2008), 'Microneedle-based drug delivery: Studies on delivery', Biomed Microdevices, 10, 601-10

Yoon, Y. K., J. H. Park and M. G. Allen (2006), 'Multidirectional UV lithography for complex 3-D MEMS structures', J. Microelectromech. Syst., 15 (5), 1121-30

Yu, W., G. Jiang, Y. Zhang, D. Liu, B. Xu and J. Zhou (2017), 'Polymer microneedles fabricated from alginate and hyaluronate for transdermal delivery of insulin', Mater Sci Eng C Mater Biol Appl. 80, 187-96

Zhang, S., Y. Qiu and Y. Gao (2014), 'Enhanced delivery of hydrophilic peptides in vitro by transdermal microneedle pretreatment', Acta Pharm Sin B, 4 (1), 100-104

Zhu, W., W. Pewin, C. Wang, Y. Luo, G. X. Gonzalez, T. Mohan, M. R. Prausnitz and B. Z. Wang (2017), 'A boosting skin vaccination with dissolving microneedle patch encapsulating M2e vaccine broadens the protective efficacy of conventional influenza vaccines', J. Control. Release, 261, 1-9.

To cite this paper please use the following details: Adeyemi, T. (2019), 'A Comprehensive Review on the Potential of Microfabricated Microneedles for Effective Systemic Delivery of Drugs ', Reinvention: an International Journal of Undergraduate Research, Volume 12, Issue 2, https://reinventionjournal.org/article/view/371. Date accessed [insert date]. If you cite this article or use it in any teaching or other related activities please let us know by e-mailing us at Reinventionjournal@warwick.ac.uk. 